\title{
CLAIMING ENHANCED EARNING CAPACITY IN MATRIMONIAL PROPERTY DISPUTES: LESSONS FROM NEW ZEALAND
}

\author{
Ravindran Nadarajan* \\ Norliah Ibrahim** \\ Najibah Mohd. Zin ${ }^{* * *}$
}

\begin{abstract}
Upon divorce, the economic disparities between the spouses are usually disputed where the non-acquiring spouse is left with little or no matrimonial property. This article discusses the application of the enhanced earning capacity principle as practiced in New Zealand in order to examine possible adoption in Malaysia. Analysis of New Zealand's judicial decisions is made in order to identify approaches in determining future assets as matrimonial property to compensate for the economic disparity between spouses. The article proceeds to consider applications of those principles by the Malaysian courts under Section 76 of Law Reform (Marriage and Divorce) Act 1976. Considering this issue, it is found that the enabling statute is New Zealand's Property (Relationships) Amendment Act 2001 recognizes that upon divorce, the enhanced earnings acquired during the marriage are subject to a division on the basis that the other spouse has also directly or indirectly contributed to compensate the economic disparity suffered by the referred spouse. The case law analysis is conducted on selected cases merely to justify on the enhanced earning capacity distributed as matrimonial property in New Zealand. Undoubtedly, the claim on enhanced earning capacity as the matrimonial property will compensate the spouse if his or her living standards and income become significantly
\end{abstract}

* Postgraduate student, Department of Civil Law, Ahmad Ibrahim Kuliyyah of Laws, International Islamic University of Malaysia. Email: itbmsu@gmail.com.my.

** Associate Professor, Department of Civil Law, Ahmad Ibrahim Kuliyyah of Laws, International Islamic University of Malaysia. Email: norliah@iium.edu.my.

*** Professor, Department of Islamic Law, Ahmad Ibrahim Kuliyyah of Laws, International Islamic University of Malaysia. Email: najibah@iium.edu.my. 
lesser than the other party due to divorce.

Keywords: matrimonial property, economic disparity, financial resource, enhanced earning capacity, spousal rights.

\title{
MENUNTUT PEROLEHAN PENDAPATAN YANG DIPERTINGKATKAN DALAM PERBINCANGAN HARTA PERKAHWINAN: PENGAJARAN DARI NEW ZEALAND
}

\begin{abstract}
ABSTRAK
Setelah bercerai, perbezaan pendapatan ekonomi pasangan biasanya dipertikaikan di mana kebanyakan pasangan yang tidak menyumbang kepada harta perkahwinansepencariaan ditinggalkan tanpa menerima harta perkahwinan. Bagi mengatasi masalah ini, Akta Pindaan Harta (Hubungan) New Zealand 2001 mengakui bahawa perolehan pendapatan yang dipertingkatkan yang telah diperolehi dalam tempoh perkahwinan dibahagikan apabila berlaku perceraian dengan alasan bahawa pasangan yang tidak bekerja juga secara langsung atau tidak langsung telah menyumbang kepada sumber kekeluargaan. Tujuannya untuk mengimbangi jurang pendapatan ekonomi yang dihadapi oleh pasangan yang dirujuk selepas bercerai. Makalah ini menganalisis keputusan kehakiman daripada New Zealand dalam menentukan perolehan pendapatan masa depan sebagai harta perkahwinan untuk mengimbangi perbezaan ekonomi antara pasangan dan penerapan prinsip-prinsip tersebut yang boleh diterima pakai oleh mahkamah Malaysia di bawah Seksyen 76 Akta Pembaharuan Undang-Undang (Perkahwinan dan Perceraian) 1976. Analisis kes dilakukan pada keskes terpilih hanya berdasarkan pada kemampuan perolehan pendapatan yang dibahagikan sebagai harta perkahwinan di New Zealand. Tidak dinafikan, tuntutan ke atas perolehan pendapatan yang dipertingkat sebagai asset yang dibahagikan dari harta perkahwinan akan memberi ganti rugi kepada pasangan sekiranya taraf hidup dan pendapatannya menjadi jauh lebih rendah daripada pasangan lain kerana perceraian.
\end{abstract}

Kata kunci: harta perkahwinan, perbezaan pendapatan ekonomi, sumber kewangan, perolehan pendapatan yang dipertingkat, kelayakkan atas harta perkahwinan. 


\section{INTRODUCTION}

In many instances of marital breakdown, a divorcee suffers the consequence of financial disadvantages due to the inapt or zero distribution of the matrimonial property. Spouses who sacrificed her/his own earning power for the sake of family welfare and children's upbringing, during the course of the marriage are often left without receiving any matrimonial property upon divorce. The discussion of whether the enhanced earning capacity constitutes a form of "property" distribution between spouses when economic disparity occurs upon divorce remains in several jurisdictions, including in New Zealand. Thus, to compensate the primary caregivers and homemakers who deliberately sacrificed their careers in marriage, New Zealand's Property (Relationships) Amendment Act $2001^{1}$ (herein referred to as "PRA") provides a new form of equality that accounts for the financial advantages and disadvantages of the spouses rather than the ordinary $50 / 50$ distribution of existing property. ${ }^{2}$ This act defines the enhanced earning capacity as a form of matrimonial property distribution according to the financial advantages and disadvantages of the spouses upon divorce.

The court also emphasised the need to rebalance any significant economic disparities between spousal incomes and living standards as a result of the divorce and the distribution of matrimonial property. The act was designated so that the distribution of enhanced earning capacity is substantially equal in terms of the overall contribution and sacrifices of the parties which may not be formally equal in monetary terms. ${ }^{3}$ Section 15 of the PRA was drafted for the sole purpose of compensating another spouse who was indirectly or directly affected due to divorce and suffers a lower income and living standards. ${ }^{4}$ For an order to be issued under Section 15, the court needs to analyse the income and living standard disparity due to divorce before awarding an

1 The original Act "Property (Relationships) Act 1976" was amended in year 2001 to include section 15 and 15A.

2 Chamberlain, N. (2018). The Future of Economic Disparity Redress in New Zealand. (2018) 28 New Zealand Universities Law Journal 293.

3 Frantz, C. J., \& Dagan, H. "Properties of marriage." (2004) Colum. L. Rev., 104, 75.

4 Atkin, B. "The Legal World of Unmarried Couples: Reflections on De Facto Relationship in Recent New Zealand Legislation." (2008) Victoria U. Wellington L. Rev.39: 793. 
equal compensation to the spouse who is most likely to suffer from the disparity. ${ }^{5}$ The case of $\mathrm{M} \mathrm{v} \mathrm{B}{ }^{6}$ proved that the analysis of earning capacity is not subjected to the distribution under maintenance, but is limited to as relationship property distribution. Therefore, prompting the court to recognise earning capacity as matrimonial property.

However, according to Malaysia's Law Reform (Marriage and Divorce) Act 1976 (hereinafter referred to as "LRA", future assets or increase in land or property value acquired by either spouse during the duration of the marriage are not recognised by the courts as matrimonial property. This view was contended since the increase in the value of a matrimonial home or an investment property can be transformed into matrimonial property upon divorce. ${ }^{7}$ Despite the distribution of these properties as matrimonial properties, the court has no specific term to identify or address as future assets or "enhanced earning capacity" of the property which also function as matrimonial properties. Nevertheless, the court does account for acquisition and contribution elements of both spouses on the properties acquired throughout the marriage.

Thus, different approaches using similar terms have been identified, where it was first supported by the Court of Appeal in Ching Seng Woah v Lim Shook $\operatorname{Lin}^{8}$ in recognising the earning capital of the matrimonial home. The earning capacity of the property can be considered as matrimonial property, subjecting it to distribution upon divorce since the value of the house will increase in the future and that the house was acquired by a spousal joint effort. The judge interpreted "earning capacity" as capital appreciation indicating that the possible increase of the market value of the property value, qualified by the requirement that the increase must be confined to the duration of the marriage. A further view as to whether it falls under the definition of matrimonial property was reluctantly withhold by the judge.

5 Parkinson, Patrick. "Family property division and the principle of judicial restraint." UNSWLJ 41 (2018): 380.

6 BC200660794, New Zealand Court of Appeal, CA13/05, at para 127.

7 Abd Ghadas, Z. A., \& Ibrahim, N. "Right of Participation in Business as Matrimonial Property: The Malaysian Experience". (2007) IIUM Law Journal 15(1).

8 [1997] 1 CLJ 375, [1997] 1 MLJ 109 at p 119, CA. 
Additionally, in the case of Yap Yen Piow v Hee Wee Eng ${ }^{9}$, the Court of Appeal's was also reluctant in its ruling to consider the value of appreciation as future assets because the term is not worded under section 76 of the LRA. The judge contended that if the parliament intended to include any terms, they should have done so. Thus, this has allowed the court to interpret the statutory provision of identifying the property that should be subjected to distribution as matrimonial property because the LRA does not give any indication on this matter. Although section 76 does not define the types of property which should be distributed as matrimonial property, any property acquired during marriage or property obtained before marriage but substantially improved during the course of marriage, can be deemed as matrimonial property.

\section{METHODOLOGY}

The methodology adopted in this research is in the form of case law and statutory analysis which are conducted on selected cases confined to the claims on the enhanced earning capacity of an asset which is the subject for distribution of matrimonial property in New Zealand. For the purposes of this research, the basic tools of data collection were notably from library resources. The analysis of the reported cases seek to examine the effectiveness of the claim on enhanced earning capacity as matrimonial property through the practice in New Zealand's family court. The statutory analysis examines the significant development of the New Zealand's Property (Relationships) Act 1976 and significant amendment in year 2001 to include Sections 15 and 15A in the existing law for further improvement of the law on the spousal right of enhance earning to be distributed as matrimonial property which could be adopted under section 76 of Malaysia's LRA.

\section{The Development of New Zealand's Property Relationship Act 1976}

Before the amendment in 2001, the claim for earning capacity was not recognised as a matrimonial property as put forth in the case of $Z v . Z$ [1997] 2 N.Z.L.R. 258. The shift of perspective occurred with the

$9 \quad[2017] 1$ MLJ 17 at $\mathrm{p} 21$. 
implementation of the new legislation which considered the spousal earning power to be subjected for distribution in relationship property. ${ }^{10}$ Earlier, "enhanced earning" was not recognised in divorce settlements, creating disadvantages to spouses who had sacrificed their time and career for the purpose of child-rearing and homemaking. This shortcoming prompted the implementation of Section 15 and Section 15A of the PRA. On assessing the applicability of Section 15 of PRA, Bill Atkin mentioned that it has provided the opportunity to consider the elements of economic disparities upon divorce in an equal distribution. ${ }^{11}$

The above finding corresponds to the notion observed by Nicola Peart, who concluded that the PRA amendment has transformed the fundamental principle of equal distribution by scrutinising the economic disparity suffered by the spouses to ensure appropriate and equitable justice. ${ }^{12}$ Sections 15 and $15 \mathrm{~A}$ of the PRA function as tools that recognise the earning power of former spouses when the disadvantages of economic disparity are encountered ${ }^{13}$ and the higher earner is subjected to share relationship property. ${ }^{14}$ Section 15 of PRA was designed to reduce hardship based on equal distribution by considering the respective spouse's earning capacities so as to encourage substantively equal positions for both spouses upon divorce. ${ }^{15}$ The recognition of enhanced earnings elements in an

10 Grainer, Virginia. “What's Yours Is Mine: Reform of the Property Division Regime for Unmarried Couples in New Zealand.” Pac. Rim L. \& Pol'y J. 11 (2002): 285. at p 296.

11 Bill Atkin "Economic disparity - how did we end up with it? Has it been worth it?" (2007) 5 NZFLJ 299.

12 Peart, Nicola. "The Property (Relationships) Amendment Act 2001: A Conceptual Change." Victoria U. Wellington L. Rev. 39 (2008): 813. at p 815.

13 Grainer, Virginia. "What's Yours Is Mine: Reform of the Property Division Regime for Unmarried Couples in New Zealand"at p 297.

14 Bill Atkin "The Legal World of Unmarried Couples - Does the New Zealand Approach Shed any Light on the Future?" 13th World Conference of the International Society of Family Law, Vienna 2008, published in (2008) 39 VUWLR 793.

15 Tasneem Haradasa, "Causation in Section 15 of the Property (Relationships) Act 1976: Analyzing the New Zealand Supreme Court's Working Assumption - Is It Really Working," Victoria University of Wellington Law Review 50, no. 1 (June 2019): 77-106. 
economic disparity claim signifies the Court's acceptance that marriage or other relationships, de facto partnerships, and civil unions are equal.

\section{Statutory and Judicial Approaches to the Spousal Rights Claim of Future Assets as Matrimonial Assets in the Property (Relationships) Amendment Act 2001.}

The wide conception of terms in of judicial approaches holds that judges should look primarily at the consensus of the overall objectives of matrimonial property when ruling equal distribution unless the elements of the contribution on property acquisition made by the other spouse proved otherwise. Thus, it is essential for the Court to construe the meaning and interpretation of terms to promote equity better in the future.

\section{Statutory Approaches}

Through careful scrutiny, sections 15 and 15A are two discretionary powers available to the Court to remedy economic disparity. ${ }^{16}$ Section 15 realises a more general discretionary power in awarding a sum of money or property out of one party's share from the relationship property pool to compensate for economic disparity as stated in the following:

(1) This section applies if, on the division of the property, the court is satisfied that, after the marriage, civil union, or de facto relationship ends, the income and living standards of one spouse or partner (party B) are likely to be significantly higher than the other spouse or partner (party A) because of the effects of the division of functions within the marriage, civil union, or de facto relationship while the parties were living together.

(2) In determining whether or not to make an order under this section, the court may have regard to -

(a) the likely earning capacity of each spouse or partner:

16 Bill Atkin and Wendy Parker Relationship Property in New Zealand (Butterworths, Wellington, 2001) at 93. 
(b) the responsibilities of each spouse or partner for the ongoing daily care of any minor or dependent children of the marriage, civil union, or de facto relationship:

(c) any other relevant circumstances.

(3) If this section applies, the court, if it considers it just, may, for the purpose of compensating party $\mathrm{A}$ -

(a) order party B to pay party A a sum of money out of party B's relationship property:

In contrast, section $15 \mathrm{~A}$ aims to compensate for the wealthier party's actions that increase their separate wealth as stated below:

(1) This section applies if, on the division of relationship property, the court is satisfied-

(a) that, after the marriage, civil union, or de facto relationship ends, the income and living standards of one spouse or partner (party $B$ ) are likely to be significantly higher than the other spouse or partner (party $A$ ) because of the effects of the division of functions within the marriage, civil union, or de facto relationship while the spouses or partners were living together; and

(b) that any increase in the value of party B's separate property was attributable, wholly or in part, and whether directly or indirectly, to the actions of party $\mathrm{B}$ while the spouses or partners were living together.

(2) In determining whether or not to make an order under this section, the court may have regard to-

(a) the likely earning capacity of each spouse or partner:

(b) the responsibilities of each spouse or partner for the ongoing daily care of any minor or dependent children of the marriage, civil union, or de facto relationship:

(c) any other relevant circumstances.

(3) If this section applies, the court, if it considers it just, may, for the purpose of compensating party A for the increase in 
value of party B's separate property, -

(a) order party B to pay party A a sum of money, whether out of relationship property or separate property:

(b) order party B to transfer to party A any other property, whether the property is relationship property or separate property.

(4) This section does not limit section 15, but overrides sections 11 to 14A.

Section 15 and 15A comprise a jurisdictional test and a broad discretionary component for court analysis. Therefore, each case offers new insights to the ruling concerning the enhanced earning capacity. ${ }^{17}$ The Court can further exercise its power to interpret the scope of Section 15 based on a wider application of future economic disparity, overcoming the problems encountered by the lower-income spouse.

\section{Judicial Approaches}

In view of the statutory approaches involved under Section 15 of the PRA, the Court in De Malmanche $v$ De Malmanche ${ }^{18}$ stressed the jurisdictional limits of the aforementioned section on the economic disparity redressing must be observed by Courts of all levels. Section $1 \mathrm{~N}(\mathrm{c})$ principle stipulates that the court should follow whatever that is stated in the stipulated section when financial advantage or disadvantage occurs between spouses upon divorce. ${ }^{19}$ Concerning this, the Court in the case of $\mathrm{P} v \mathrm{P}^{20}$ held concerns about the interpretation and application of Section 15 on the Property (Relationships) Act 1976, concluding that the economic disparity that exists between spouses upon divorce should be compensated. ${ }^{21}$ Furthermore, the

17 Joanna Miles, "Dealing with Economic Disparity: An Analysis of Section 15 Property (Relationships) Act 1976," New Zealand Law Review 2003, no. 4 (2003): 535-568 at p 538.

18 [2002] NZFLR 579 at para 22.

19 Ibid at para [155].

20 [2005] NZFLR 689.

21 Ibid at p 693. 
apportionment details to be distributed under Section 15(2) of PRA require analysis of spousal earning abilities of spouses and their duty in child-rearing and homemaking. ${ }^{22}$ It is indisputable that the earning abilities of the spouse who sacrificed their career or took care of their children at home, to support the other spouse are bound to suffer from economic disparity due to divorce. Hence, many courts are reliant on Section 15 of PRA to ensure equity between spouses by evaluating earning capacity and economic disparity.

The High Court heralds a significant and welcome change to the application of Section 15 of the Property (Relationships) Act 1976 in the case of Jack $v$ Jack, ${ }^{23}$, upholding Carpenter $v$ Carpenter. ${ }^{24}$ The decision, in this case, upheld the Family Court's verdict of awarding 70 per cent of the relationship property to the wife for her contribution in 24 years marriage in helping her husband and caring for the children and the home, sacrificing her potential earning. In 2017, the Supreme Court for the first time considered Section 15 in its decision in Scott $v$ Williams. ${ }^{25} \mathrm{Mr}$ Williams has a partnership in a legal firm and Ms Scott was a professional accountant and lawyer. Since the birth of the couple's first child, Ms Scott had her work hours reduced. She completely stopped work after their second child was born, who required significant medical care in the first eight years of his life. Ms Scott did assist in doing the accounts for Mr Williams' firm on a parttime basis. The Supreme Court of New Zealand granted Ms Scott $\$ 520,000$ under Section 15 of the Property (Relationships) Act 1976 as amended in the year 2001 following the economic disparity between the spouses. ${ }^{26}$ In New Zealand, under Section 15 of the Property (Relationships) Amendment Act 2001, the Court is allowed to make a fair order and an equitable distribution based on the economic disparity suffered by spouses upon divorce or separation in the name of matrimonial property, ensuring equity instead of equality for both spouses. $^{27}$

\footnotetext{
22 Ibid at $\mathrm{p} 709$.

23 [2014] NZHC 1495.

24 [2013] NZFC 8396, [2014] NZFLR 9.

25 [2017] NZSC 185, [2018] 1 NZLR 507.

26 At Para 477

27 Henaghan, M., \& Ballantyne, R. (2015). Recent Changes to the Division of Relationship Property in New Zealand: A New Way Forward. International Surv. Fam. L., at p 229.
} 


\section{Discussion and Analysis.}

New Zealand under Section 15 of the PRA emphasised on the claim on the future assets or enhanced earning as matrimonial property where the court must do so upon the analysis of spousal earning abilities and their duty in caring for their children mainly when economic disparity arises upon divorce. Similarly, Malaysia can participate in emphasising spousal equity by considering any property acquired during the marriage as matrimonial property if either spouse can prove their acquisition or contribution elements under Section 76 of the LRA. It has been a norm for the court, to distribute matrimonial property under section 76 of LRA, which only defined the property such as house, land, car and tangible assets as matrimonial property, even though the section 76 of LRA is not clearly defined on the types of property which should be distributed as matrimonial property. Thus, Malaysia can look to New Zealand and their approaches taken in Section 15 of the PRA in considering a different dimension of defining property types when solving the issues of spousal economic disparities. It is proven that by amending New Zealand's relationship property to include the terms 'financial resource' or 'future assets' under the matrimonial property, numerous cases in New Zealand were compensated equally in matrimonial property distribution. The amendment ensured the broader scope of matrimonial property for a fair and just distribution among spouses, especially in ensuring the welfare of the spouse and the children (if any) who suffer from the disadvantage of economic disparity. This approach can be used as a guide for Malaysia. Hence, spousal rights on the matrimonial property can be acknowledged regardless of who owned or contributed to the said property during the marriage. 